\title{
Implications of volatile fatty acid profile on the metabolic pathway during continuous sulfate reduction
}

\author{
Sueli M. Bertolino, Isabel C.B. Rodrigues, Renata Guerra-Sá, Sérgio F. Aquino, Versiane A. Leão* \\ Universidade Federal de Ouro Preto, Campus Morro do Cruzeiro, s.n., Ouro Preto 35400-000, MG, Brazil
}

\section{A R T I C L E I N F O}

\section{Article history:}

Received 15 August 2011

Received in revised form

30 January 2012

Accepted 18 February 2012

Available online 28 March 2012

\section{Keywords:}

UASB reactor

Sulfate reduction

Lactate

Propionate

Fermentation

Metabolic pathways

\begin{abstract}
A B S T R A C T
Volatile fatty acid (VFA) profile is an important parameter in anaerobic reactors because it enables the assessment of metabolic pathways. Volatile fatty acids were monitored during sulfate reduction in a UASB (upflow anaerobic sludge blanket) reactor treating $2 \mathrm{~g} / \mathrm{L}$ sulfate concentration and with the organic loading increasing from $3.5 \mathrm{~kg} \mathrm{COD} / \mathrm{m}^{3} \mathrm{~d}$ to $5.9 \mathrm{~kg} \mathrm{COD} / \mathrm{m}^{3} \mathrm{~d}$, for a 1-day residence time. In the absence of recirculation, the best outcome ( $65 \%$ reduction) was noticed with the lowest organic loading $\left(3.55 \mathrm{~kg} / \mathrm{m}^{3} \mathrm{~d}\right)$. When recirculation was applied, sulfate reduction yields increased to $89 \%$, corresponding to a sulfate removal rate of $1.94 \mathrm{~kg} \mathrm{SO}_{4}^{2-} / \mathrm{m}^{3} \mathrm{~d}$. The reactor performance was discussed in relation to microbial diversity and metabolic pathways. At high organic loading, two metabolic pathways account for lactate degradation: (i) lactate is oxidized to acetate and carbon dioxide by the incomplete-oxidizer SRB (sulfate-reducing bacteria) Desulfomonas, Desulfovibrio, Desulfolobus, Desulfobulbus and Desulfotomaculum spp.; (ii) lactate is converted to acetate by fermenting bacteria such as Clostridium sp. High propionate concentrations imply that there are low sulfate reduction efficiencies.
\end{abstract}

(c) 2012 Elsevier Ltd. All rights reserved.

\section{Introduction}

Sulfate is always present in effluents from the chemical, metallurgical and pharmaceutical industries because of the widespread use of sulfuric acid. The former can also be produced during natural oxidation of sulfide minerals. Although sulfate is considered a low-risk substance when compared to dissolved metals and acidity, regulatory agencies are becoming increasingly concerned about high sulfate levels in effluents and stricter standards are being imposed or expected in the near future (INAP, 2003; USEPA, 2009; WHO, 2008).

The treatment of sulfate containing wastewaters comprises both biological and chemical processes. Chemical processes can sometimes be expensive and produce a high volume of sludge. Biological treatment uses sulfate-reducing bacteria (SRB), which is present in many anaerobic wastewater treatment systems and this route has been extensively studied because sulfate and metal concentrations can be reduced to very low levels, sludge production is minimal and

\footnotetext{
* Corresponding author. Bio\&Hydrometallurgy Laboratory, Department of Metallurgical and Materials Engineering, Universidade Federal de Ouro Preto, Campus Morro do Cruzeiro, s.n., Bauxita, Ouro Preto 35400-000, MG, Brazil. Tel.: +55 313559 1102; fax: +55 3135591561 .

E-mail addresses: versiane@demet.em.ufop.br, versiane.ufop@gmail.com (V.A. Leão).
}

the precipitated metal sulfides can be sold; reducing operational costs. Conversely, biological sulfate reduction economics relies heavily on the carbon source and the process is also influenced by temperature; and thereby drainage heating in moderate climates may be required.

SRB utilize easily degradable organic compounds, including lactate, which can be oxidized by different species (Barton, 1995; Liamleam and Annachhatre, 2007). When lactate is biologically degraded, volatile fatty acids (VFA) such as pyruvate, acetate, propionate and butyrate can be produced (García, 1982). These compounds can also be degraded by either SRB or other microorganisms. As such the VFA profile can be related to the different phenomena occurring in anaerobic reactors (acidogenesis, sulfidogenesis and methanogenesis) (Aquino and Chernicaro, 2005), supporting a discussion on the metabolic pathways accounting for sulfate reduction and organic matter oxidation.

The upflow anaerobic sludge blanket (UASB) is an established anaerobic reactor. Its advantages as compared to other anaerobic reactors include low investment and energy costs, and short hydraulic retention time with no support medium required (Lettinga and Hulshoff Pol, 1991) i.e. it has an simple and inexpensive design. It has some disadvantages regarding sulfate reduction: namely (i) mixing is provided solely by the flow rate because gas production is low or inexistent and (ii) SRB does not granulate as well as methanogenic microorganisms. Nevertheless, 
this reactor has been investigated for sulfate reduction in many studies where different carbon sources (Gonçalves et al., 2007; Harada et al., 1994; Lopes et al., 2007, 2010; Poinapen et al., 2009; Vallero et al., 2003) as well as reactor operational configurations were studied (Kaksonen et al., 2004; Mohan et al., 2005b; Shayegan et al., 2005).

Two types of studies can be cited regarding anaerobic sulfate reduction. The first type are works where lab-scale UASB reactors are investigated and parameters such as substrate type, $\mathrm{COD} /$ sulfate ratio and sulfate loads are studied (Gonçalves et al., 2007; Kaksonen et al., 2003a; Kosinska and Miskiewicz, 2009; Lopes et al., 2007; Mohan et al., 2005a; Poinapen et al., 2009; Shayegan et al., 2005; Vallero et al., 2003). Usually, lactate is not the chosen substrate (due to economic constraints) and no detailed discussion on the metabolic pathways is carried out. The second group of studies, usually performed in chemostats (Dar et al., 2008; Zhao et al., 2008), investigates metabolic pathways with the support of molecular biology. In this second group, lactate is the preferred carbon and electron source because it enables the growth of different SRB strains, as stated. Therefore, this work is an attempt to apply these two approaches to discuss comprehensively the performance of a UASB reactor treating high sulfate loads. Lactate was chosen as the carbon source as it enables a deeper understanding of the different phases occurring in anaerobic reactors.

\section{Experimental}

\subsection{Microorganisms and growth medium}

The inoculum used in this study was obtained from a granular sludge collected from an UASB reactor treating domestic wastewater and enriched in a modified Postgate $C$ medium so that a $5-\mathrm{L}$ sample was produced. The enrichment medium was comprised of: $0.5 \mathrm{~g} / \mathrm{L} \mathrm{KH} \mathrm{PO}_{4} ; 1.0 \mathrm{~g} / \mathrm{L} \mathrm{NH} \mathrm{H}_{4} \mathrm{Cl} ; 0.06 \mathrm{~g} / \mathrm{L} \mathrm{MgSO}_{4} \cdot 7 \mathrm{H}_{2} \mathrm{O} ; 0.1 \mathrm{~g} / \mathrm{L} \mathrm{FeS}-$ $\mathrm{O}_{4} \cdot 7 \mathrm{H}_{2} \mathrm{O} ; 0.25 \mathrm{~g} / \mathrm{L}$ yeast extract; $2.96 \mathrm{~g} / \mathrm{L} \mathrm{Na} \mathrm{SO}_{4} ;$ and $3.76 \mathrm{~g} / \mathrm{L}$ lactate. Afterward, the inoculum, containing $7.6 \mathrm{~g}$ VSS (volatile suspended solids) was transferred to the reactor and pumping of the growth medium containing sulfate was started in a semi-batch mode. This process involved $24 \mathrm{~h}$ of growth medium pumping and 24-h rest periods so that adaptation to the new reactor (UASB) was accomplished. As soon as the whole reactor was filled with the medium and biomass, the continuous operation was started.

\subsection{Anaerobic reactor and operational methods}

Fig. 1 shows a schematic diagram of the of lab-scale UASB reactor (1). The total volume was $3.0 \mathrm{~L}$ and it was placed inside a fume hood in a temperature-controlled room whereby the temperature was maintained at $25 \pm 2{ }^{\circ} \mathrm{C}$. Three sampling ports ( $a$, $b$ and $c$ ), a gas outlet (5), completed the reactor. A peristaltic pump (3) pumped the solution (growth medium) from the feed tank (2) into the reactor (1). For recirculation, a second pump (4) was added and the solution from port $c$ was recycled. The effluent was collected in a second tank (6).

This reactor operated during 580 days, at an hydraulic retention time (HRT) of $24 \mathrm{~h}$ and was fed with a synthetic effluent (modified Postage C medium, Section 2.1) containing lactate as the only carbon and electron source. The organic load varied according to the sulfidogenic performance shown by the reactor, starting at a COD/sulfate mass ratio of 1.8 (Table 1 ). Phases I and II represented the SRB enrichment period, whereas phases III to $\mathrm{V}$ were run with increasing organic load for a constant sulfate concentration $(2.0 \mathrm{~g} /$ $\mathrm{L}$ ). Phase VI is characterized by effluent recirculation (rate $=93$ ), for an organic load rate (OLR) set at $5 \mathrm{~kg} \mathrm{COD} / \mathrm{m}^{3} \mathrm{~d}(\mathrm{COD} /$ sulfate $=2.5)$. The reactor effluent was analyzed twice a week for total (data not

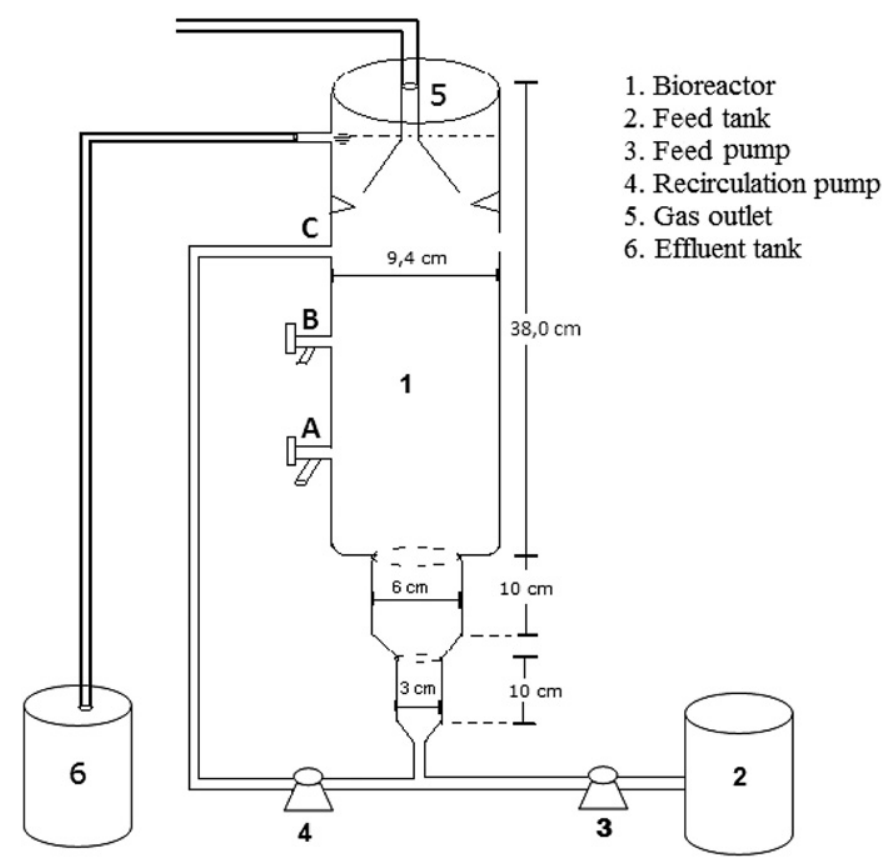

Fig. 1. Schematic diagram of the UASB reactor for sulfate reduction.

shown) and filtered chemical oxygen demand (COD), sulfate, alkalinity, VFA, volatile suspended solids (VSS), $\mathrm{pH}$ and redox potential (Eh). Once a week, a sample from inside the reactor was withdrawn for measuring VSS, alkalinity, $\mathrm{pH}$ and redox potential, whereas viable cells were determined monthly.

\subsection{Analytical methods}

Sulfate concentration was determined by ionic chromatography (Metrohm) using an ASSUP-10 column and conductivity detection. VFA (acetic, propionic, valeric, butyric) were analyzed by high performance liquid chromatography (HPLC, Shimadzu), with an ion exchange column Aminex HPX-87H $300 \mathrm{~mm} \times 7.8 \mathrm{~mm}$ (Bio-Rad). Prior to injection, samples were filtered using $0.22 \mu \mathrm{m}$ membrane filters (Millipore, Corp.). Bicarbonate alkalinity (BA) was assayed by titration with $0.1 \mathrm{M}$ sulfuric acid solution to $\mathrm{pH} 4.5$; VSS and COD according to the Standard Methods for Water and Wastewater (APHA, 2005). Before COD determination, any sulfide present in effluent samples was removed by adding a drop of $\mathrm{HCl}(35 \%)$ and flushing the sample for 10 min with $\mathrm{N}_{2}$. The solution's pH (Hanna $\mathrm{HI931400}$ ) and its redox potential (Digimed) (vs an $\mathrm{Ag} / \mathrm{AgCl}$ electrode) were also recorded.

Microorganisms were enumerated by a three-tube most probable number (MPN) procedure in a specific medium for SRB (Postgate C) (Postgate, 1963). Prior to the experiments, culture

Table 1

Operational parameters during sulfate reduction in the UASB reactor. Hydraulic retention time: $24 \mathrm{~h}, 25^{\circ} \mathrm{C}$.

\begin{tabular}{lrllll}
\hline Phases & \multicolumn{1}{l}{ Days } & OLR $^{\mathrm{a}}\left(\mathrm{kg} / \mathrm{m}^{3} \mathrm{~d}\right)$ & $\mathrm{COD}^{\mathrm{b}}(\mathrm{mg} / \mathrm{L})$ & $\mathrm{SO}_{4}^{2-}(\mathrm{mg} / \mathrm{L})$ & $\mathrm{COD} / \mathrm{SO}_{4}^{2-}$ ratio \\
\hline $\mathrm{I}$ & $42-114$ & $3.48 \pm 0.33$ & $3512 \pm 325$ & $1967 \pm 189$ & $1.80 \pm 0.20$ \\
$\mathrm{II}$ & $115-216$ & $4.87 \pm 0.30$ & $5000 \pm 280$ & $1964 \pm 101$ & $2.55 \pm 0.20$ \\
III & $217-317$ & $3.55 \pm 0.25$ & $3645 \pm 304$ & $2200 \pm 197$ & $1.67 \pm 0.18$ \\
IV & $318-368$ & $4.65 \pm 0.30$ & $4790 \pm 396$ & $2037 \pm 226$ & $2.39 \pm 0.33$ \\
V & $369-445$ & $5.89 \pm 0.48$ & $6040 \pm 411$ & $1944 \pm 97$ & $3.12 \pm 0.28$ \\
VI & $499-578$ & $5.04 \pm 0.33$ & $5200 \pm 332$ & $2046 \pm 140$ & $2.52 \pm 0.21$ \\
\hline
\end{tabular}

a OLR: organic loading rate.

b COD: chemical oxygen demand. 
tubes were degassed with pure $\mathrm{N}_{2}$, sealed and autoclaved $\left(120^{\circ} \mathrm{C}\right.$, $1.5 \mathrm{~atm}, 20 \mathrm{~min}$ ). Afterward, culture tubes and the control tube were incubated for 30 days, at $35^{\circ} \mathrm{C}$.

16S rRNA gene sequences were utilized to study bacterial phylogeny and taxonomy present in the sludge inoculum and in the reactor during phases I (enrichment) and IV (OLR). Briefly, the 16S rRNA amplicons of all samples were cloned into pGEMT-Easy vector and then sequenced in an ABI 3100 automated sequencer (Applied Biosystem), using a dye terminator kit. The sequences were then used for phylogenic analysis. Experimental details were described in Rampinelli et al. (2008).

\section{Results and discussion}

\subsection{Reactor start-up and biomass}

Total biomass and SRB population were followed by the biomass weight (as VSS) and the MPN technique, respectively. The results, depicted in Fig. 2, were assessed at the end of each phase and show a 1000-time increase in the SRB population from phase I $\left(5.3 \times 10^{6}\right.$ cells $\left./ \mathrm{mL}\right)$ to phase III $\left(9.5 \times 10^{9}\right.$ cells $\left./ \mathrm{mL}\right)$. This linear increase suggests that up to phase III, the SRB population had not reached its maximum value. This is consistent with other works in which a long lag period was required to stabilize the SRB population (Beaulieu et al., 2000; Omil et al., 1998). Similar populations were determined by Mizuno et al. (1998), studying sulfate reduction with sucrose in batch reactors. After phase III, the VSS values stabilized in the range 7.62-13.61 g VSS, without large variations. In addition, the changes in the SRB population, after phase III, reflect the changes in the COD/sulfate mass ratio as will be discussed throughout this work.

Microbial diversity was determined in the sludge inoculum and in the reactor during phases I (enrichment) and IV (OLR). The enrichment procedure successfully resulted in a diverse SRB population as shown in Table 2, while inhibiting the growth of methanogens, as the latter were not identified in the inoculum. Nevertheless, methane-producing microorganisms (MPN) were identified in all samples taken from the reactor (phases I and IV). This microbial diversity was expected, due to the inoculum origin (domestic sewage treating reactor). In addition, enrichment with Postgate $C$ medium induced, as expected, the growth of incomplete oxidizers - those microorganisms which oxidize lactate to acetate, such as the Desulfomonas, Desulfovibrio, Desulfolobus, Desulfobulbus

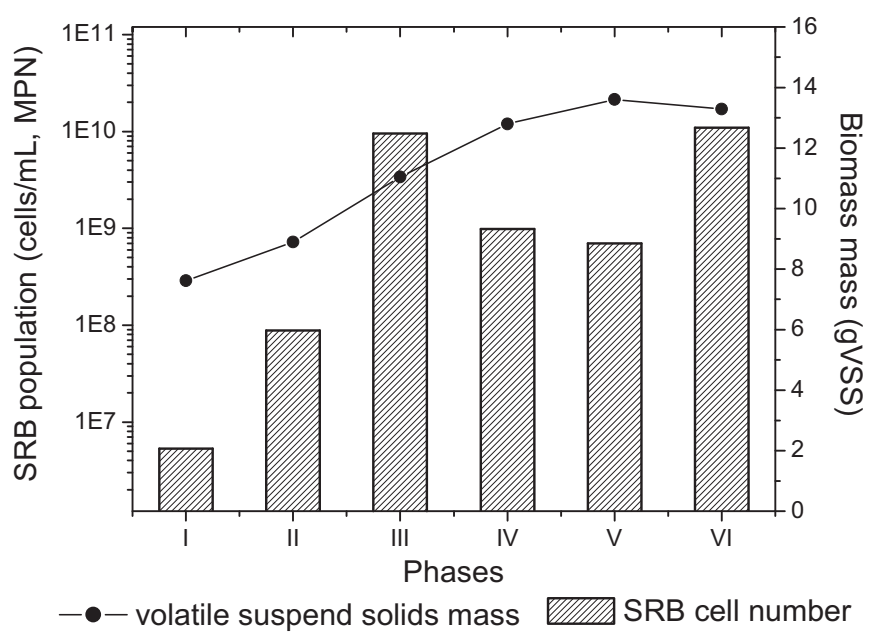

Fig. 2. Evolution of biomass monitored in the UASB reactor: (I) $\mathrm{OLR}=3.48 \mathrm{~kg} / \mathrm{m}^{3} \mathrm{~d}$; (II) OLR $=4.87 \mathrm{~kg} / \mathrm{m}^{3} \mathrm{~d} ; \quad$ (III) $\quad$ OLR $=3.55 \mathrm{~kg} / \mathrm{m}^{3} \mathrm{~d} ; \quad$ (IV) $\quad$ OLR $=4.65 \mathrm{~kg} / \mathrm{m}^{3} \mathrm{~d} ; \quad$ (V) OLR $=5.89 \mathrm{~kg} / \mathrm{m}^{3} \mathrm{~d} ;(\mathrm{VI})$ OLR $=5.04 \mathrm{~kg} / \mathrm{m}^{3} \mathrm{~d}$.
Table 2

Microorganisms identified by molecular biology techniques in the inoculum and different phases during UASB reactor operation.

\begin{tabular}{|c|c|c|c|}
\hline Microorganism & \multirow{2}{*}{$\begin{array}{l}\begin{array}{l}\text { Start-up } \\
\text { inoculum }\end{array} \\
+\end{array}$} & \multirow{2}{*}{$\begin{array}{l}\text { UASB phase } \\
\text { I and IV } \\
+\end{array}$} & \multirow{2}{*}{$\begin{array}{l}\text { Similarity }^{\mathrm{b}} \\
\% \\
100\end{array}$} \\
\hline 1. Desulfomonas pigra (SF192152) (IO) & & & \\
\hline $\begin{array}{l}\text { 2. Desulfovibrio desulfuricans subsp. } \\
\text { Desulfuricans str. ATCC } 27774 \text { (IO) }\end{array}$ & + & + & 100 \\
\hline 3. Desulfolobus sp. (IO) & + & + & 100 \\
\hline 4. Desulfovibrio vulgaris (IO) & + & + & 100 \\
\hline $\begin{array}{l}\text { 5. Uncultured Desulfovibrio sp. clone } \\
\text { A37bac } 16 \mathrm{~S} \text { ribosomal(IO) }\end{array}$ & + & + & 100 \\
\hline 6. Desulfobulbus sp. (EF442937) (PO) & + & + & 100 \\
\hline 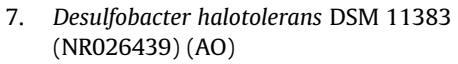 & + & + & 100 \\
\hline $\begin{array}{l}\text { 8. Uncultured Desulfotomaculum sp. } \\
\text { Clone BNB-488 (FJ898345) (IO) }\end{array}$ & + & + & 100 \\
\hline 9. Methanogens & - & + & 100 \\
\hline 10. Clostridium sp. & a & + & 100 \\
\hline
\end{tabular}

IO - lactate incomplete-oxidizer SRB to acetate.

$\mathrm{PO}$ - propionate-oxidizer SRB to acetate.

AO - acetate-oxidizer SRB.

a Not analyzed.

b DNA sequence deposited in gene Bank.

and Desulfotomaculum genera. It must be pointed out that although methanogens were detected in phases I and IV, their growth is more inhibited by the presence of sulfide (especially $\mathrm{H}_{2} \mathrm{~S}$ ) as compared to SRB (O'Flaherty et al., 1998b). Therefore, their population was expected to decrease, as the SRB predominated in the reactor and sulfate reduction increased (Bhattacharya et al., 1996; Briones et al., 2009; Omil et al., 1998).

\subsection{Reactor performance}

\subsubsection{Parameters}

The process stability in the UASB reactor was monitored by $\mathrm{pH}$, redox potential $(\mathrm{Ag} / \mathrm{AgCl})$, VFA concentration and alkalinity (Fig. 3), whereas, the performance of sulfate reduction was investigated by the amount of sulfate and COD removed as well as the VFA profile.

The optimum $\mathrm{pH}$ for SRB growth is around 7 and lower values $(\mathrm{pH}<5)$ affect bacterial growth (Barton, 1995). Furthermore the VFA accumulation and alkalinity production, both resulting from organic matter degradation, will define the effluent $\mathrm{pH}$ (Fig. 3A). Fig. 3B shows that VFA concentration steadily increased from $2000 \mathrm{mg} / \mathrm{L}$ to $4000 \mathrm{mg} / \mathrm{L}$ which is neutralized by alkalinity $(\sim 1500 \mathrm{mg} / \mathrm{L})$ produced during lactate oxidation, which is sufficient for maintaining the $\mathrm{pH}$ in a range that enables SRB growth. The $\mathrm{pH}$ inside the reactor remained fairly constant up to phase III (6.8) and a slight reduction was noticed as a result of higher VFA production in phases IV $(\mathrm{pH}=6.6)$ and $\mathrm{V}(\mathrm{pH}=6.4)$, likely derived from increased organic load (Fig. $3 \mathrm{~A}$ ). The $\mathrm{pH}$ increased to values above 7, when recirculation was started (phase VI), in which more alkalinity was produced as compared to the previous phases. This behavior is a result of a higher sulfate reduction in this latter phase (Table 3, reaction 2); thereby recirculation can be an alternative to external alkalinity addition to maintain $\mathrm{pH}$ conditions suitable for SRB development. The solution redox potential reflects the reducing conditions in the UASB reactor (Fig. $3 \mathrm{~A}$ ) and decreased as sulfate reduction improved. It also enabled a quick assessment of the operational conditions of the reactor.

\subsubsection{COD removal efficiency and sulfate reduction}

In a previous work with this inoculum, a COD/sulfate mass ratio of 2.0 was optimum for the bacterial growth and sulfate reduction in batch conditions, resulting in $98 \%$ sulfate removal (Barbosa et al., 2009). Therefore, this value was chosen for the phase I (start-up enrichment), although the actual values were slightly smaller 

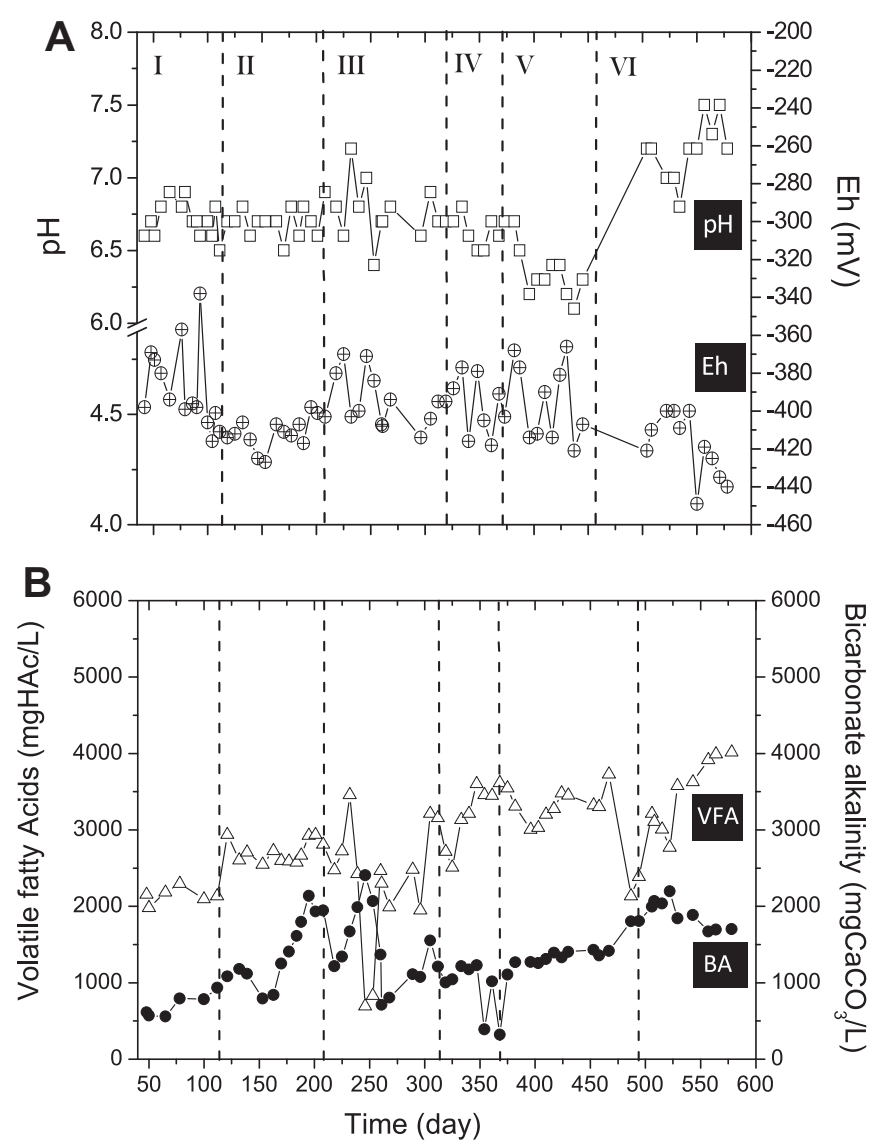

Fig. 3. Performance parameters of the UASB reactor, in different phases (according to Table 1). VFA: volatile fatty acids; BA: bicarbonate alkalinity.

(Table 1). Afterward, during phases III to $\mathrm{V}$, the organic loading was changed according to both SRB concentration and sulfate reduction yields in the previous phases. These variations are shown in Fig. 4. During phases I $\left(3.48 \pm 0.33 \mathrm{~kg} \mathrm{COD} / \mathrm{m}^{3} \mathrm{~d}\right)$ and II $\left(4.87 \pm 0.30 \mathrm{~kg} \mathrm{COD} / \mathrm{m}^{3} \mathrm{~d}\right.$ ) (Fig. $\left.4 \mathrm{~A}\right)$, the average organic matter consumption was $25 \%$ and $22 \%$ respectively (Fig. $4 \mathrm{~B}$ ). Furthermore, for an SRB population of $5.3 \times 10^{6}$ SRB cells/mL (Fig. 2), $51 \%$ of the oxidized organic matter was utilized for a $36 \%$ sulfate reduction (phase I). Similarly, during phase II, a population of $8.8 \times 10^{7}$ SRB cells/mL utilized $58 \%$ of the transferred electrons for a $49 \%$ sulfate reduction. At phase III, the SRB population increased considerably $\left(9.5 \times 10^{9}\right.$ SRB cells $\left./ \mathrm{mL}\right)$ and removed $40 \%$ of the COD and $65 \%$ of the sulfate, implying that $60 \%$ of the electron flux was utilized for sulfate reduction at a rate of $1.29 \mathrm{~kg} \mathrm{SO}_{4}^{2-} / \mathrm{m}^{3} \mathrm{~d}$ (Fig. 4C). Sulfate reduction improved up to phase IV (88\%) (Fig. 4D) but the organic loading of $4.65 \pm 0.30 \mathrm{~kg} \mathrm{COD} / \mathrm{m}^{3} \mathrm{~d}$ resulted in a higher VFA production, i.e. increased lactate fermentation, which decreased

Table 3

Anaerobic degradation reactions relevant to this study.

\begin{tabular}{llc}
\hline$\#$ & Chemical reaction & $\Delta G O^{\prime}(\mathrm{kJ})$ \\
\hline 1 & 2lactate $+3 \mathrm{SO}_{4}^{2-} \rightarrow 6 \mathrm{HCO}_{3}^{-}+3 \mathrm{HS}^{-}+\mathrm{H}^{+}$ & -225.3 \\
2 & 2lactate $+\mathrm{SO}_{4}^{2-} \rightarrow$ 2acetate $+2 \mathrm{HCO}_{3}^{-}+\mathrm{HS}^{-}+\mathrm{H}^{+}$ & -160.1 \\
3 & 3lactate $\rightarrow$ acetate +2 propionate $+\mathrm{HCO}_{3}^{-}+\mathrm{H}^{+}$ & -169.7 \\
4 & propionate $+\mathrm{SO}_{4}^{2-}+\mathrm{H}_{2} \rightarrow$ acetate $+2 \mathrm{HCO}_{3}^{-}+\mathrm{HS}^{-}+\mathrm{H}_{2} \mathrm{O}$ & -75.8 \\
5 & acetate $+\mathrm{SO}_{4}^{-2} \rightarrow 2 \mathrm{HCO}_{3}^{-}+\mathrm{HS}^{-}$ & -47.8 \\
6 & $4 \mathrm{H}_{2}+\mathrm{SO}_{4}^{2-}+\mathrm{H}^{+} \rightarrow \mathrm{HS}^{-}+4 \mathrm{H}_{2} \mathrm{O}$ & -151.9 \\
7 & $4 \mathrm{H}_{2}+\mathrm{HCO}_{3}^{-}+\mathrm{H}^{+} \rightarrow \mathrm{CH}_{4}+3 \mathrm{H}_{2} \mathrm{O}$ & -153.6 \\
8 & acetate $+\mathrm{H}_{2} \mathrm{O} \rightarrow \mathrm{CH}_{4}+\mathrm{HCO}_{3}^{-}$ & -31.0 \\
9 & propionate $+3 \mathrm{H}_{2} \mathrm{O} \rightarrow$ acetate $+\mathrm{HCO}_{3}^{-}+\mathrm{H}^{+}+3 \mathrm{H}_{2}$ & +76.1 \\
\hline
\end{tabular}

sulfate reduction to a minimum of $32 \%$ at the later stages of this phase. This behavior is consistent with the work of Ren et al. (2007). At an even higher organic loading of $5.89 \mathrm{~kg} \mathrm{COD} / \mathrm{m}^{3} \mathrm{~d}$ (phase V), no improvement on reactor performance was observed and a reduction on COD consumption to $23 \%$, coupled with a sulfate reduction efficiency that varied between $39 \%$ and $72 \%$, was noticed. Analysis of the COD consumption as a function of the organic load is carried out in the next section.

As stated, up to phase $\mathrm{V}$, increased lactate concentration did not improve sulfate reduction, as the residual sulfate concentration of the reactor effluent was fairly high $(780 \mathrm{mg} / \mathrm{L}$, on the average). Alternatively, it was decided to recirculate the effluent and this is represented by phase VI. For $5.0 \mathrm{~kg} C O D / \mathrm{m}^{3} \mathrm{~d}$ (similar to that applied in phase IV), reactor performance improvement was clear as sulfate reduction increased from $65 \%$ to $89 \%$ ( $235 \mathrm{mg} / \mathrm{L}$ residual sulfate) for a COD consumption of $41 \%$. This value is consistent with the work of Kaksonen et al. (2003a) under similar conditions.

\subsubsection{Volatile fatty acids profile and sulfate reduction}

Microbial species identified in the inoculum and on the reactor biomass are depicted in Table 2. Furthermore, Table 4 presents data of fed lactate (determined from the measured COD) and measured sulfate, acetate and propionate concentrations during the different phases. Table 4 also shows the fraction of lactate utilized during sulfate reduction as predicted by reaction 2 , Table 3 . The selection of reaction 2 as the main sulfate reduction pathway was supported by alkalinity measured (Fig. 3B) during the experiment, which would be two times higher if direct oxidation to bicarbonate was the main reaction (reaction 1 , Table 3 ). From the five VFAs analyzed, only acetate and propionate were detected and accounted for the high VFA concentrations observed in the UASB reactor (Fig. 3B). This result is consistent with the works of Zhao et al. (2008) and Lopes et al. (2010), which also observed sulfate reduction under acidogenic conditions. The implications of these parameters on the reactor performance are discussed in the following paragraphs.

The parameters shown in Table 4 and Fig. 2 along with the microbial characterization (Table 2) indicate two metabolic pathways for lactate degradation (Fig. 5): (i) lactate is first oxidized to pyruvate following to acetate by incomplete-oxidizers SRB; in which Desulfovibrio sp. plays a key role (reaction 2, Table 3); (ii) lactate is fermented by the propionate CoA-transferase enzyme produced by fermenting bacteria such as Clostridium sp. (reaction 3 , Table 3) (Barton, 1995; García, 1982). These observations are supported by the acetate and propionate accumulation in the reactor (Table 4). Moreover, the results here achieved suggest that the predominant metabolic pathway is defined by: (i) lactate (or COD)/ sulfate mol ratio, (ii) SRB population (bacterial counts) and (iii) the reactor hydrodynamics. Fig. $6 \mathrm{~A}$ depicts both the measured acetate concentration and that predicted by reaction 2 (determined from the reduced sulfate), Table 4 . This latter was added to that produce by reaction 3 , assuming that the lactate not consumed by reaction 2 was converted to acetate. Unlike phase II, the values predicted by the two metabolic pathways are in agreement with the measured concentrations. Similarly, Fig. 6B presents actual and predicted (reaction 3, Table 3 ) propionate concentrations. Fairly good agreement between the experimental results and the predicted concentrations during phases I to IV was also noticed. The higher than expected propionate concentration observed in phases IV and $\mathrm{V}$ suggests that reaction 2 itself does not account for sulfate reduction. It is likely that hydrogen produced during lactate fermentation mainly in phase V (Garcia et al., 2001) was used as an electron donor for sulfate reduction (reaction 6). In the study of Hwang et al. (2009) hydrogen gas production was not significant at lower $\mathrm{COD} /$ sulfate ratios, but at the highest organic loading, it became important. It must be stressed that Desulfovibrio species 

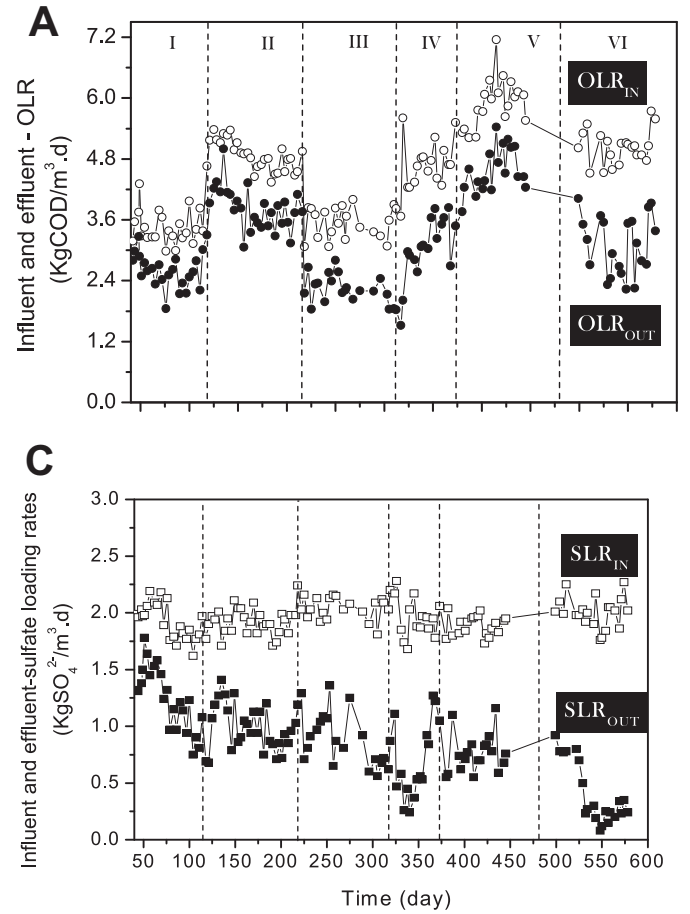

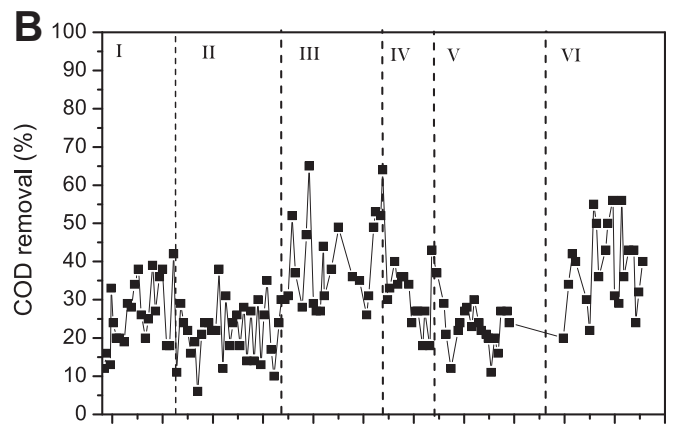

D

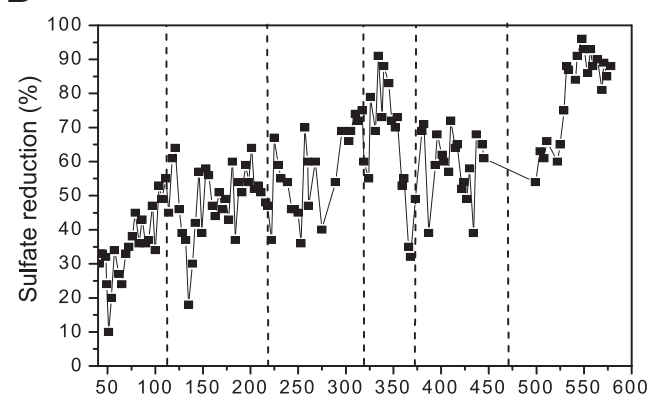

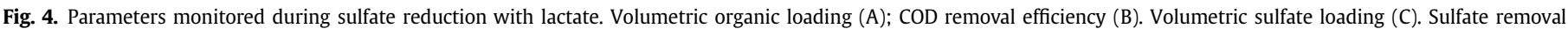
efficiency (D), during the phases I-VI (according to Table 1).

can grow with both lactate and hydrogen gas as electron donors (Barton, 1995).

When reactor performances with the same lactate concentration in the feed are compared (phases I and III - $37 \mathrm{mmol} / \mathrm{L}$ lactate), it was noticed that the predominant metabolic pathway during lactate degradation (oxidation or fermentation) was defined by the SRB population. In phase I, a low population of $5.3 \times 10^{6}$ SRB cells/ $\mathrm{mL}$ (Fig. 2) used $40 \%$ of the fed lactate $(37 \mathrm{mmol} / \mathrm{L}$ ) to reduce $7.25 \mathrm{mmol} / \mathrm{L}$ of the sulfate (following reaction 2 , Table 3 ). The remaining lactate $(22.4 \mathrm{mmol} / \mathrm{L})$ was thus fermented and produced propionate (reaction 3 , Table 3 ), which is consistent with the measured propionate concentration $(12.9 \pm 3.3 \mathrm{mmol} / \mathrm{L})$ as shown in Fig. 6B. Therefore, during phase I, the dominant reaction in this reactor seemed to be lactate fermentation to propionate which may have been carried out by Clostridium sp. (Table 2). In this phase, the measured acetate concentrations ( $18.41 \pm 3.2 \mathrm{mmol} / \mathrm{L}$, Fig. $6 \mathrm{~A})$ are similar to that resulting from reactions 2 and 3 occurring in the reactor. The incomplete lactate oxidation by SRB (reaction 2 ) would produce $14.5 \mathrm{mmol} / \mathrm{L}$ acetate and lactate fermentation (reactor 3) another $7.4 \mathrm{mmol} / \mathrm{L}$ acetate.

Likewise during phase III and at the same lactate concentration, but with a higher SRB population $\left(9.5 \times 10^{9} \mathrm{SRB}\right.$ cells $\left./ \mathrm{mL}\right)$, reaction

Table 4

Parameters related to sulfate removal in the UASB reactor as a function of feed lactate concentration.

\begin{tabular}{lllllllll}
\hline \multirow{2}{*}{ Parameters } & \multirow{2}{*}{ Unit } & \multicolumn{7}{c}{ Phases monitored } \\
\cline { 3 - 8 } & & & $\mathrm{I}$ & $\mathrm{II}$ & $\mathrm{III}$ & $\mathrm{IV}$ & $\mathrm{V}$ & $\mathrm{VI}$ \\
\hline Influent lactate $^{\mathrm{a}}$ & $\mathrm{mmol} / \mathrm{L}$ & 37.24 & 52.57 & 38.06 & 49.81 & 63.43 & 54.16 \\
Sulfate removal & $\mathrm{mmol} / \mathrm{L}$ & 7.25 & 9.95 & 12.89 & 13.96 & 12.13 & 17.23 \\
Acetate analytical & $\mathrm{mmol} / \mathrm{L}$ & 18.41 & 43.33 & 25.07 & 28.83 & 38.66 & 47.00 \\
Propionate analytical & $\mathrm{mmol} / \mathrm{L}$ & 12.87 & 19.83 & 9.06 & 19.52 & 37.88 & 7.74 \\
Oxidized lactate $^{\mathrm{b}}$ & $\%$ & 40 & 38 & 68 & 56 & 38 & 64 \\
\hline
\end{tabular}

a Determined from the measured COD in the reactor feed.

b Lactate oxidized was calculated from reduced sulfate according to reaction 2 (Table 3 ) divided by the influent lactate concentration.
2 predicts that reducing $12.89 \mathrm{mmol} / \mathrm{L}$ of sulfate (analytical value), would require $25.8 \mathrm{mmol} / \mathrm{L}$ ( $68 \%$ of the initial concentration) of lactate and $25.8 \mathrm{mmol} / \mathrm{L}$ of acetate would also be produced. The measured acetate concentration $(25.2 \pm 6.8 \mathrm{mmol} / \mathrm{L})$ is consistent with such analysis. Analyzing reaction 3 it can be predicted that the remaining lactate $(12.3 \mathrm{mmol} / \mathrm{L})$ was fermented to produce $4.1 \mathrm{mmol} / \mathrm{L}$ of acetate (reaction 3 ) and $8.2 \mathrm{mmol} / \mathrm{L}$ propionate and this pathway is also supported by the measured propionate concentration $(9.1 \mathrm{mmol} / \mathrm{L})$.

Organic loading effects on sulfate reduction and microbial population can be assessed by comparing phases III to $\mathrm{V}$, since both parameters are known to affect sulfate reduction (Lens et al., 2003; Reis et al., 1988; Sipma et al., 1999). In these three phases, the SRB population stabilized within the $10^{8}-10^{9}$ cells/mL range and it could be inferred that an increase in lactate concentration did not result in larger sulfate reduction yields, since the sulfate reduction was higher in phase IV $(4.8 \pm 0.4 \mathrm{gCOD} / \mathrm{L})$ than in phase $\mathrm{V}$, when the COD was increased to $6.0 \mathrm{~g} / \mathrm{L}$ (Table 1 and Fig. 4). During phase III, $68 \%$ of the fed lactate $(38 \mathrm{mmol} / \mathrm{L}$ ) was used to reduce $13 \mathrm{mmol} / \mathrm{L}$ of the sulfate. However, as the lactate concentration was increased to $50 \mathrm{mmol} / \mathrm{L}$ (phase IV), the sulfate reduction represented $56 \%$ of lactate degradation; whereas at phase $\mathrm{V}$, when lactate concentration increased further to $63 \mathrm{mmol} / \mathrm{L}$, only $38 \%$ the lactate oxidation seemed to be coupled to the reduction of $12 \mathrm{mmol} / \mathrm{L}$ of the sulfate by SRB. Such results show that even at high organic loadings, sulfate reduction is not complete and it seems that fermentation is being promoted; i.e. as the $\mathrm{COD} /$ sulfate mass ratio increased, the sulfate reduction rate also increased, but the fraction of the organic matter effectively used for sulfate reduction was reduced, indicating that the organic matter was being fermented (SRB or Clostridium), which had also been observed by Ren et al. (2007). MPM, which were proposed by many works (Kalyuzhnyi and Fedorovich, 1998; O'Flaherty et al., 1998a; Omil et al., 1998) as the main competitors with SRB for substrate oxidation, do not seem to be important in the present work. The third effect accounting for the 


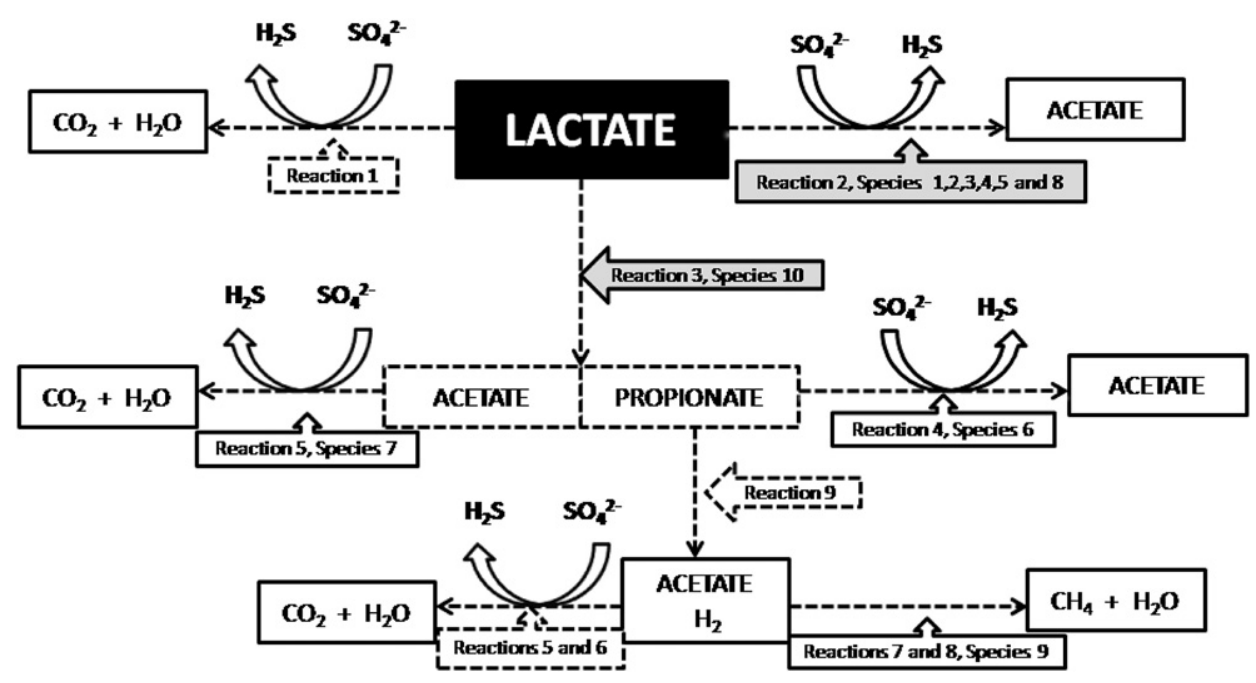

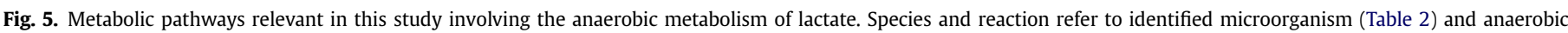
degradation reactions (Table 3 ).

predominant metabolic pathway is recirculation that will be discussed in the next part of the present work.

Table 2 indicates the absence of SRB that oxidizes lactate to $\mathrm{CO}_{2}$ (Barton, 1995) in the reactor so that reaction 1 (Table 3) was not expected to occur. Analyzing the SRB population, only one acetateoxidizer SRB was detected (Desulfobacter halotolerans). Furthermore, methanogens were also observed and both (methanogens and $D$. halotolerans) can oxidize acetate. Nevertheless, as acetate accumulated in the effluent during the sulfate reduction in all of the phases $(\mathrm{I}-\mathrm{VI})$, it can be inferred that none of them predominated in the reactor. This would explain the high acetate concentrations observed $(1100-2600 \mathrm{mg} / \mathrm{L})$ in the effluent and is consistent with the work of Lopes et al. (2010), who studied thermophilic sulfate reduction with sucrose $(2.0 \mathrm{~g} / \mathrm{L})$ as electron donor. As the kinetics of sulfate reduction and organic matter oxidation is compared, acetate oxidation is the limiting step during both sulfate reduction and methane production (Aquino and Chernicaro, 2005; Colleran et al., 1995; Kaksonen et al., 2006). This behavior is because both acetateoxidizer SRB and acetate-reducing MPM have small growth rates i.e., specific growth rate $\left(\mu_{\max }\right)$ values that vary from 0.002 to $0.068 \mathrm{~h}^{-1}$ for the former (Elferink et al., 1998; Lawrence and Marchant, 1991) and from 0.0046 to $0.01 \mathrm{~h}^{-1}$ for MPM (Kalyuzhnyi and Fedorovich, 1998; Zuhair et al., 2008). For sulfate reduction via incomplete lactate oxidation, much higher $\mu_{\max }$ values are reported, ranging from 0.23 to $0.498 \mathrm{~h}^{-1}$ (Kaksonen et al., 2003b; Widdel, 1988; Zuhair et al., 2008). Therefore kinetic effects account for the acetate presence in the reactor for the same residence time. As Fig. $6 \mathrm{~A}$ shows, the acetate concentrations predicted by reactions 2 and 3 (Table 3 ), are similar to that actually measured, supporting the proposed metabolic pathways.

MPM growth is also partially inhibited by high sulfide concentrations during sulfidogenesis (Dar et al., 2008; Kaksonen et al., 2003a; Nagpal et al., 2000; Omil et al., 1998). However, different species have different tolerances to total sulfide and Chen et al., (2008) suggests that sulfide inhibition ranges from $100 \mathrm{mg} / \mathrm{L}$ to $800 \mathrm{mg} / \mathrm{L}$ in the case of the bisulfide ion $\left(\mathrm{HS}^{-}\right.$) or $50-400 \mathrm{mg} / \mathrm{L}$ when the predominant species is $\mathrm{H}_{2} \mathrm{~S}$. He also indicated that fermentative bacteria are less affected by the sulfide concentration than acetoclastic SRB and methanogens. Considering the SRB group, incomplete-oxidizers SRB are less affected by sulfide than complete oxidizers SRB (Kaksonen and Puhakka, 2007). In the present study, the $\mathrm{pH}$ inside the UASB reactor remained in the 6.4-6.8 range; thereby some $25 \%$ and $75 \%$ of the total sulfide was estimated to be present as $\mathrm{HS}^{-}$and $\mathrm{H}_{2} \mathrm{~S}$, respectively. Moreover during phases IV and $\mathrm{V}$, the total sulfide concentration varied from $184 \mathrm{mg} / \mathrm{L}$ to $250 \mathrm{mg} / \mathrm{L}$, which was smaller than the value predicted when the sulfate reduction yields were analyzed. This lower than expected value could be a result of $\mathrm{H}_{2} \mathrm{~S}$ volatilization during the
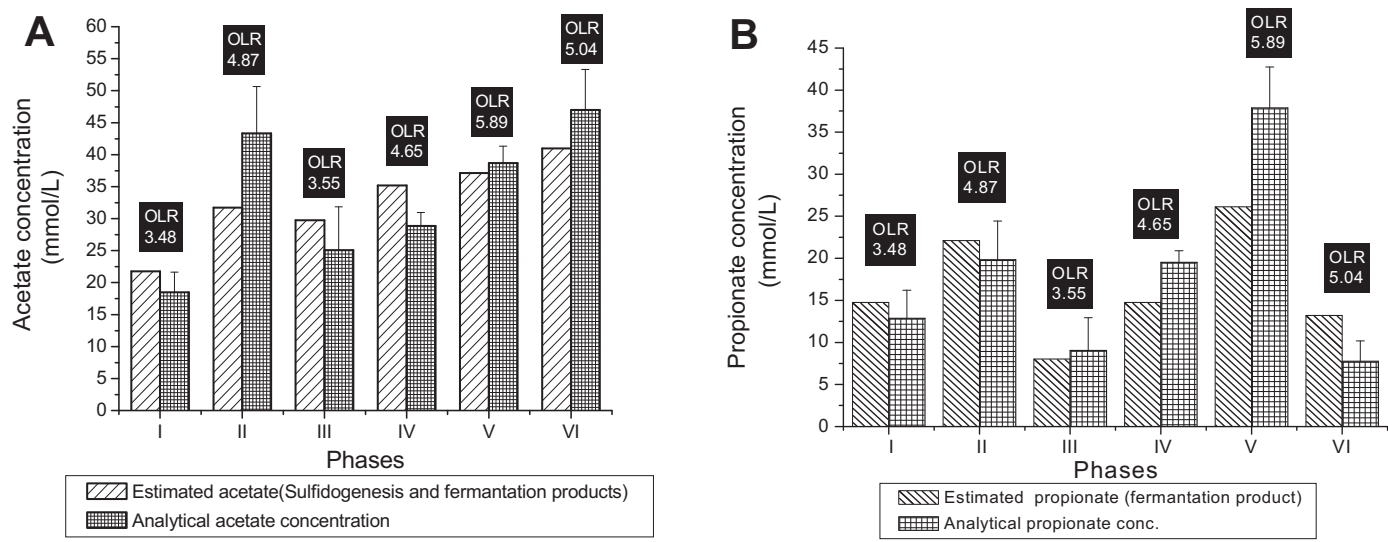

Fig. 6. Comparison between estimated and analytical concentrations of: (A) acetate; (B) propionate, during phases I-VI (Table 1$)$. OLR: organic load rate (kg/ $\left.{ }^{3} \mathrm{~d}\right)$. 
experimental runs (parameter not followed). Nevertheless, the measured $\mathrm{H}_{2} \mathrm{~S}$ concentration is high enough to inhibit acetate oxidation by either acetoclastic SRB or methanogens. For instance it has been shown that $270 \mathrm{mg} \mathrm{H}_{2} \mathrm{~S} / \mathrm{L}$ and $160 \mathrm{mg} \mathrm{H}_{2} \mathrm{~S} / \mathrm{L}$ accounted for a $50 \%$ inhibition on acetoclastic SRB and methanogens growth, respectively (Yamaguchi et al., 1999).

Propionate presence in the reactor effluent is an indication of fermenting microorganisms (Dar et al., 2008), which also produces acetate. Assuming the predominance of incomplete-oxidizers SRB in the reactor, an estimate of propionate concentration can be performed from the lactate concentration not used for sulfate reduction (Table 4), since lactate was not detected in the reactor effluent. The absence of lactate can be verified by reaction 1 that presents a mass balance for the COD measured in the system.

$\mathrm{COD}_{\text {removed }}=\mathrm{COD}_{\text {in }}-\mathrm{COD}_{\text {out }}$

and

$\mathrm{COD}_{\text {out }}=\mathrm{COD}_{\mathrm{VFA}}+\mathrm{COD}_{\mathrm{TDS}}+\mathrm{COD}_{\text {residual }}$

where $\mathrm{COD}_{\text {in }}$ and $\mathrm{COD}_{\text {out }}$ are the chemical oxygen demand in the reactor influent and effluent, respectively; CODVFA corresponds to VFA (acetate and propionate solely); $\mathrm{COD}_{\mathrm{TDS}}$, to sulfide ions and $\mathrm{COD}_{\text {residual, }}$, to any lactate remaining in the system. Sulfide ions were removed from the reactor effluent sample by acidification and stripping (Celis-Garcia et al., 2007); whereas bacterial cells did not contribute to the measured COD, due to membrane filtration prior to analysis. Therefore, $\mathrm{COD}_{\text {out }}$ is achieved from $\mathrm{COD}_{\mathrm{VFA}}$ and $\mathrm{COD}_{\mathrm{re}}$ sidual, as shown in equation 1 . It can be noticed in Fig. 7, that the $\mathrm{COD}_{\text {out }}$ value is similar or smaller than $\mathrm{COD}_{\mathrm{VFA}}$; whereupon no residual lactate was expected. It was likely degraded to either acetate (by either SRB or fermentative microorganisms, or both) or propionate (fermentative microorganisms).

By analyzing the propionate profile (Fig. 6B), its concentration in the phases where SRB population was low (I and II) could be predicted (assuming that the lactate not consumed by reaction 2 was converted to propionate by reaction 3 ) fairly accurately, i.e. lactate fermentation to acetate and propionate. Conversely, in the phases where the SRB population was high $\left(>10^{8}\right.$ cells $/ \mathrm{mL}$ ), propionate concentration increased (from $9.06 \mathrm{mmol} / \mathrm{L}$ in phase III to $37.88 \mathrm{mmol} / \mathrm{L}$ in phase $\mathrm{V}$ ) with the organic load, suggesting a high fermentative activity that decreased the specific sulfate reduction rate from values above $0.075 \mathrm{~g} \mathrm{SO}_{4}^{2-} / \mathrm{g} \mathrm{SSV} \mathrm{d}$ to lower yields

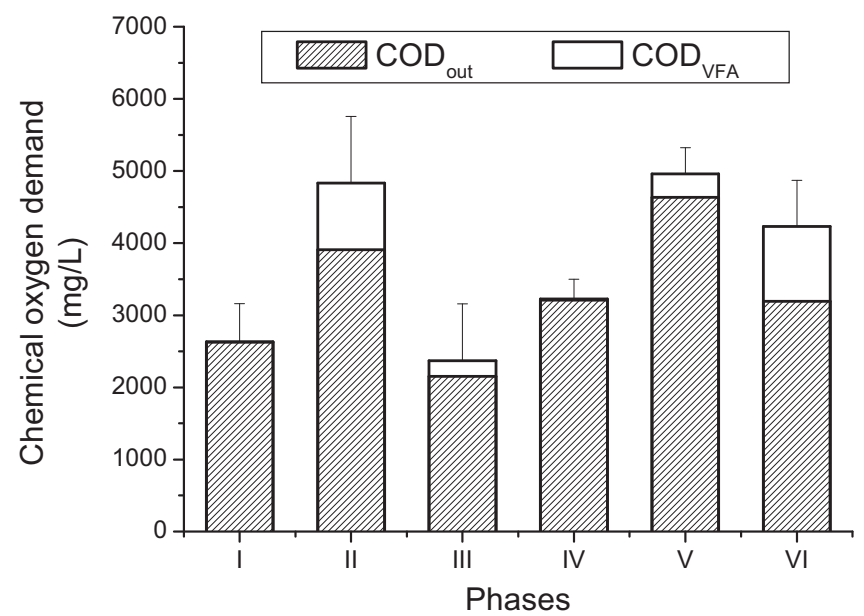

Fig. 7. Values of effluent- and $C O D_{V F A}$ during sulfate reduction in the UASB reactor. $\mathrm{COD}_{\text {out }}$ was measured and $\mathrm{COD}_{\mathrm{VFA}}$ values were determined from the measured propionate and acetate concentrations.
( $\left.0.060 \mathrm{~g} \mathrm{SO}_{4}^{2-} / \mathrm{g} \mathrm{SSV} \mathrm{d}\right)$. Similar behavior was observed by Dar et al. (2008) who detected propionate at a low sulfate concentration (20 mM lactate and $10.3 \mathrm{mM}$ sulfate), indicating that lactate fermented. Oyekola et al. (2009) also observed similar results when the reactor dilution rate was high, which was related to faster lactate fermentation as compared to sulfate reduction.

SRB can degrade organic compounds by diverse metabolic pathways but most Desulfovibrio species do not grow in the presence of volatile fatty acids (Barton, 1995). Therefore, increased propionate concentration indicates lower growth rates of Desulfobulbus, the only propionate-degrading SRB identified in the UASB reactor. Another possibility would be propionate degradation by syntrophic microorganisms following reaction 9 (Table 3 ). However, this reaction is not supposed to occur in the presence of high acetate concentrations (Aquino and Chernicaro, 2005). Notwithstanding, propionate concentration was decreased when recirculation was applied as will be discussed next.

\subsubsection{Influence of effluent recirculation in sulfate reduction}

As shown in Fig. 6, when the organic loading was high (phases III, IV and V), there was propionate build-up (due to lactate fermentation), which may be ascribed to poor sludge granulation and a low upflow velocity in the UASB reactor (Steed et al., 2000). With recirculation (Phase VI), propionate concentration reduced from almost $40 \mathrm{mmol} / \mathrm{L}$, at phase $\mathrm{V}\left(5.89 \mathrm{~kg} / \mathrm{m}^{3} \mathrm{~d}\right)$ to values below $10 \mathrm{mmol} / \mathrm{L}$ at a similar organic loading rate $\left(5.04 \mathrm{~kg} / \mathrm{m}^{3} \mathrm{~d}\right)$. This latter propionate concentration is similar to that observed during phase III $(\sim 10 \mathrm{mmol} / \mathrm{L})$, when the organic loading was only $3.55 \mathrm{~kg} / \mathrm{m}^{3} \mathrm{~d}$. As already stated, Desulfobulbus can degrade propionate (reaction 4 , Table 3 ), but its growth rate is small - in the range $0.037-0.11 \mathrm{~h}^{-1}$ (Kalyuzhnyi and Fedorovich, 1998; O'Flaherty et al., 1998a) - as compared to those bacteria belonging to the Desulfovibrio genera. The applied recirculation rate was 93 , which resulted in increased upflow velocities (from $0.02 \mathrm{~m} / \mathrm{h}$ to $1.75 \mathrm{~m} / \mathrm{h}$ ), thereby improving the mass transfer in the reactor. Considering reaction 2 (Table 3 ) as the main metabolic pathway for lactate oxidation during sulfate reduction (89\%), along with reaction 3 , and assuming that the residual lactate had been used for the propionate production, nearly $1017 \mathrm{mg} / \mathrm{L}$ propionate was expected in the reactor. As the measured propionate concentration was $596 \pm 188 \mathrm{mg} / \mathrm{L}$, it is therefore proposed that the propionate oxidation by Desulfobulbus became relevant in this phase. Lactate fermentation to propionate followed by its oxidation by Desulfobulbus was also observed by Dar et al. (2008) and Zhao et al. (2008) who attributed high sulfate reduction yields to propionate oxidation.

The present work suggests that regardless of the substrate being degraded, the performance of an UASB reactor can be followed by the VFA profile. For instance, the propionate presence could be taken as an indication of fermentation, which is an important metabolic pathway and this would imply in low sulfate reduction efficiency. Ideally, an UASB reactor for sulfate reduction would not produce propionate at optimum sulfate reduction conditions. Nevertheless, the residual COD is high and requires downstream treatment but it is likely to be easily degradable, due to the presence of only acetate $(47 \mathrm{mmol} / \mathrm{L})$ and propionate $(8 \mathrm{mmol} / \mathrm{L})$ when lactate is the only carbon source.

\section{Conclusions}

This work showed that the best results of a UASB reactor for sulfate reduction were achieved for $\mathrm{COD} /$ sulfate mass ratios in the 1.7-2.5 range, in the presence of fermentative, methanogenic microorganism and for a low diversity of acetoclastic bacteria, but enriched in an incompletely-oxidizing SRB. At either low SRB 
concentration $\left(10^{6}\right.$ cells $\left./ \mathrm{mL}\right)$ or high organic loading $(6.0 \mathrm{~kg} \mathrm{COD} /$ $\mathrm{m}^{3} \mathrm{~d}$ ), fermentation was the main metabolic pathway; thereby, acetate and propionate were predominant in the reactor. Conversely, for a high SRB population $\left(10^{9}\right.$ cells $\left./ \mathrm{mL}\right)$ and lower organic loading ( $3.55 \mathrm{COD} \mathrm{kg} / \mathrm{m}^{3} \mathrm{~d}$.), sulfate reduction becomes the main metabolic pathway and an average sulfate reduction value of $66 \%$ was observed without recirculation in the reactor treating $2.0 \mathrm{~g} / \mathrm{L}$ sulfate for a $24 \mathrm{~h}$ residence time. Sulfate reduction increased to $89 \%$ ( $\left.0.087 \mathrm{~g} \mathrm{SO}_{4}^{2-} / \mathrm{g} \mathrm{SSV} \mathrm{d}\right)$ and resulted in an increase in acetate concentrations couple to low propionate content as recirculation was applied. High propionate levels are an indication of lactate fermentation whereupon sulfate reduction was impaired.

\section{Acknowledgments}

The financial support from the funding agencies FINEP, FAPEMIG, CNPq, CAPES as well as Vale is gratefully appreciated. The "Conselho Nacional de Pesquisas - CNPq scholarships to S. M. Bertolino and S. F. Aquino R. Guerra-Sá, V. A. Leão are especially acknowledged.

\section{References}

APHA, 2005. Standard Methods for the Examination of Water and Wastewater, 20th ed.. Washington, DC.

Aquino, S.F., Chernicaro, C.A., 2005. Build up of volatile fatty acids (VFA) in anaerobic reactors under stress conditions: causes and control strategies. Engenharia Sanitaria e Ambiental 10 (2), 152-161.

Barbosa, L.P., Bertolino, S.M., Freitas, P.C., Oliveira, V.A., Pina, P.D., Leão, V.A., Teixeira, M.C., 2009. Effects of different COD/sulfate ratios on the growth of metal tolerant sulfate reducing bacteria (SRB), biohydrometallurgy: a meeting point between microbial ecology, metal recovery process and environmental remediation. In: Proceedings of Biohydrometallurgy, Bariloche, pp. 569-572.

Barton, L.L., 1995. Sulfate-Reducing Bacteria. Plenum Press, New York.

Beaulieu, S., Zagury, G.J., Deschênes, L., Samson, R., 2000. Bioactivation and bioaugmentation of a passive reactor for acid mine drainage treatment. In: Singhal, R.K., Mehrotra, A.K. (Eds.), Environmental Issues and Management of Waste in Energy and Mineral Production, pp. 533-537. Rotterdam, The Netherlands.

Bhattacharya, S.K., Uberoi, V., Dronamraju, M.M., 1996. Interaction between acetate fed sulfate reducers and methanogens. Water Res. 30, 2239-2246.

Briones, A.M., Daugherty, B.J., Angenent, L.T., Rausch, K., Tumbleson, M., Raskin, L., 2009. Characterization of microbial trophic structures of two anaerobic bioreactors processing sulfate-rich waste streams. Water Res. 43, 4451.

Celis-Garcia, L.B., Razo-Flores, E., Monroy, O., 2007. Performance of a down-flow fluidized-bed reactor under sulfate reduction conditions using volatile fatty acids as electron donors. Biotechnol. Bioeng. 97, 771-779.

Chen, Y., Cheng, J.J., Creamer, K.S., 2008. Inhibition of anaerobic digestion process: a review. Bioresour. Technol. 99, 4044-4064.

Colleran, E., Finnegan, S., Lens, P., 1995. Anaerobic treatment of sulphate-containing waste streams. Anton. Leeuw. 67, 29-46.

Dar, S., Kleerebezem, R., Stams, A., Kuenen, J., Muyzer, G., 2008. Competition and coexistence of sulfate-reducing bacteria, acetogens and methanogens in a labscale anaerobic bioreactor as affected by changing substrate to sulfate ratio. Appl. Microbiol. Biotechnol. 78, 1045-1055.

Elferink, S.J.W.H.O., Luppens, S.B.I., Marcelis, C.L.M., Stams, A.J.M., 1998. Kinetics of acetate oxidation by two sulfate reducers isolated from anaerobic granular sludge. Appl. Environ. Microbiol. 64, 2301-2303.

Garcia, C., Moreno, B.A., Ballester, A., Blázques, M.L., González, F., 2001. Bioremediation of an industrial acid mine water by metal tolerant sulphate-reducing bacteria. Miner. Eng. 14, 997-1008.

García, J.L., 1982. Relations between acidogenesis and the utilization of lactate, sulfate and nitrate during anaerobic digestion. In: Simposio Panamericano de Combustibles y Productos Químicos Vía Fermentación “Avances en Digestión Anaeróbica", Mexico City, Mexico, pp. 20-30.

Gonçalves, M.M.M., Costa, A.C.A., Leite, S.G.F., Sant'Anna Jr., G.L., 2007. Heavy metal removal from synthetic wastewaters in an anaerobic bioreactor using stillage from ethanol distilleries as a carbon source. Chemosphere 69, 1815-1820.

Harada, H., Uemura, S., Momonoi, K., 1994. Interaction between sulfate-reducing bacteria and methane-producing bacteria in UASB reactors fed with low strength wastes containing different levels of sulfate. Water Res. 28, 355-367.

Hwang, J.-H., Cha, G.-C., Jeong, T.-Y., Kim, G.-J., Bhatnagar, A., Min, B., Song, H., Choi, J.-A., Lee, J.-H., Jeong, D.-W., Chung, H.-K., Park, Y.-T., Choi, J., AbouShanab, R.A.I., Oh, S.E., Jeon, B.-H., 2009. Effect of $\mathrm{COD} / \mathrm{SO}_{4}^{2-}$ ratio and $\mathrm{Fe}(\mathrm{II})$ under the variable hydraulic retention time (HRT) on fermentative hydrogen production. Water Res. 43, 3525-3533.

INAP, 2003. Treatment of Sulphate in Mine Effluents. International Network for Acid Prevention, p. 129.
Kaksonen, A., Franzmann, P., Puhakka, J., 2003a. Performance and ethanol oxidation kinetics of a sulfate-reducing fluidized-bed reactor treating acidic metalcontaining wastewater. Biodegradation 14, 207-217.

Kaksonen, A.H., Plumb, J.J., Franzmann, P.D., Puhakka, J.A., 2004. Simple organic electron donors support diverse sulfate-reducing communities in fluidized-bed reactors treating acidic metal- and sulfate-containing wastewater. FEMS Microbiol. Ecol. 47, 279-289.

Kaksonen, A.H., Plumb, J.J., Robertson, W.J., Riekkola-Vanhanen, M., Franzmann, P.D., Puhakka, J.A., 2006. The performance, kinetics and microbiology of sulfidogenic fluidized-bed treatment of acidic metal- and sulfate-containing wastewater Hydrometallurgy 83, 204-213.

Kaksonen, A.H., Puhakka, J.A., 2007. Sulfate reduction based bioprocesses for the treatment of acid mine drainage and the recovery of metals. Eng. Life Sci. 7, $541-564$.

Kaksonen, A.H., Riekkola-Vanhanen, M., Puhakka, J.A., 2003b. Optimization of metal sulphide precipitation in fluidized-bed treatment of acidic wastewater. Hydrometallurgy 37, 255-266.

Kalyuzhnyi, S.V., Fedorovich, V.V., 1998. Mathematical modelling of competition between sulphate reduction and methanogenesis in anaerobic reactors. Bioresour. Technol. 65, 227-242.

Kosinska, K., Miskiewicz, T., 2009. Performance of an anaerobic bioreactor with biomass recycling, continuously removing COD and sulphate from industrial wastes. Bioresour. Technol. 100, 85-90.

Lawrence, R.W., Marchant, P.M., 1991. Acid Rock Drainage Prediction Manual: A Manual of Chemical Evaluation Procedures for the Prediction of Acid Generation from Mine Wastes. CANMET (Canadian Centre for Mineral and Energy Technology), Vancouver, BC, Canada, p. 47.

Lens, P.N.L., Gastesi, R., Lettinga, G., 2003. Use of sulfate reducing cell suspension bioreactors for the treatment of $\mathrm{SO}_{2}$ rich flue gases. Biodegradation 14 , $229-240$.

Lettinga, G., Hulshoff Pol, L.W., 1991. UASB - process design for various types of wastewater. Water Sci. Technol. 24 (8), 87-107.

Liamleam, W., Annachhatre, A.P., 2007. Electron donors for biological sulfate reduction. Biotechnol. Adv. 25, 452-463.

Lopes, S.I.C., Capela, M.I., Lens, P.N.L., 2010. Sulfate reduction during the acidification of sucrose at pH 5 under thermophilic $\left(55^{\circ} \mathrm{C}\right)$ conditions. II: effect of sulfide and $\mathrm{COD} / \mathrm{SO}_{4}^{2-}$ ratio. Bioresour. Technol. 101, 4278-4284.

Lopes, S.I.C., Wang, X., Capela, M.I., Lens, P.N.L., 2007. Effect of $\mathrm{COD} / \mathrm{SO}_{4}^{2-}$ ratio and sulfide on thermophilic $\left(55^{\circ} \mathrm{C}\right)$ sulfate reduction during the acidification of sucrose at pH 6. Water Res. 41, 2379-2392.

Mizuno, O., Li, Y.Y., Noike, T., 1998. The behavior of sulfate-reducing bacteria in acidogenic phase of anaerobic digestion. Water Res. 32, 1626-1634.

Mohan, S.V., Prasad, K.K., Rao, N.C., Bhaskar, Y.v., Babu, V.L., Rajagopal, D., Sarma, P.N., 2005a. Biological treatment of low-biodegradable composite chemical wastewater using upflow anaerobic sludge blanket (UASB) reactor. Process monitoring. J. Sci. Ind. Res. 64, 771-777.

Mohan, S.V., Rao, N.C., Prasad, K.K., Sarma, P.N., 2005b. Bioaugmentation of an anaerobic sequencing batch biofilm reactor (AnSBBR) with immobilized sulphate reducing bacteria (SRB) for the treatment of sulphate bearing chemical wastewater. Process Biochem. 40, 2849.

Nagpal, S., Chuichulcherm, S., Peeva, L., Livingston, A., 2000. Microbial sulfate reduction in a liquid-solid fluidized bed reactor. Biotechnol. Bioeng. 70, $370-380$.

O'Flaherty, V., Lens, P., Leahy, B., Colleran, E., 1998a. Long-term competition between sulphate-reducing and methane-producing bacteria during full-scale anaerobic treatment of citric acid production wastewater. Water Res. 32, 815-825.

O'Flaherty, V., Mahony, T., Kennedy, O., Colleran, E., 1998b. Effect of pH on growth kinetics and sulphide toxicity thresholds of a range of methanogenic, syntrophic and sulphate-reducing bacteria. Process Biochem. 33 (5), 555-569.

Omil, F., Lens, P., Visser, A., Hulshoff Pol, L.W., Lettinga, G., 1998. Long-term competition between sulfate reducing and methanogenic bacteria in UASB reactors treating volatile fatty acids. Biotechnol. Bioeng. 57, 676-685.

Oyekola, O.O., van Hille, R.P., Harrison, S.T.L., 2009. Study of anaerobic lactate metabolism under biosulfidogenic conditions. Water Res. 43, 3345-3354.

Poinapen, J., Ekama, G.A., Wentzel, M.C., 2009. Biological sulphate reduction with primary sewage sludge in an upflow anaerobic sludge bed (UASB) reactor part 3: performance at $20^{\circ} \mathrm{C}$ and $35^{\circ} \mathrm{C}$. Water SA 35 (5).

Postgate, J.R., 1963. Versatile medium for the enumeration of sulfate-reducing bacteria. Appl. Microbiol. 11, 265-267.

Rampinelli, L., Azevedo, R., Teixeira, M., Guerra-Sá, R., Leão, V., 2008. A sulfatereducing bacterium with unusual growing capacity in moderately acidic conditions. Biodegradation 19, 613-619.

Reis, M.A.M., Gonçalves, L.M.D., Carrondo, M.J.T., 1988. Sulfate reduction in acidogenic phase anaerobic digestion. Water Sci. Technol. 20, 345-351.

Ren, N.-Q., Chua, H., Chan, S.-Y., Tsang, Y.-F., Sin, N., 2007. Effect of COD/SO2- ratios on an acidogenic sulfate-reducing reactor. Ind. Eng. Chem. Res. 46, 406-411.

Shayegan, J., Ghavipanjeh, F., Mirjafari, P., 2005. The effect of influent COD and upward flow velocity on the behaviour of sulphate-reducing bacteria. Process Biochem. 40, 2305-2310.

Sipma, J., Lens, P., Vieira, A., Miron, Y., van Lier, J.B., Hulshoff Pol, L.W., Lettinga, G. 1999. Thermophilic sulphate reduction in upflow anaerobic sludge bed reactors under acidifying conditions. Process Biochem. 35, 509-522.

Steed, V.S., Suidan, M.T., Gupta, M., Miyahara, T., Acheson, C.M., Sayles, G.D., 2000. Development of a sulfate-reducing biological process to remove heavy metals from acid mine drainage. Water Environ. Res. 72, 530-535. 
USEPA, 2009. 2009 Edition of the Drinking Water Standards and Health Advisories Tables. U.S. Environmental Protection Agency, Washington, DC, p. 18.

Vallero, M.V.G., Treviño, R.H.M., Paulo, P.L., Lettinga, G., Lens, P.N.L., 2003. Effect of sulfate on methanol degradation in thermophilic $\left(55^{\circ} \mathrm{C}\right)$ methanogenic UASB reactors. Enzyme Microb. Technol. 32, 676.

WHO, 2008. Guidelines for Drinking-Water Quality, third ed., Genebra, p. 668.

Widdel, F., 1988. Microbiology and Ecology of Sulfate- and Sulfur-Reducing Bacteria Biology of Anaerobic Microorganisms. John Willey \& Sons, New York, pp. 469-585.
Yamaguchi, T., Harada, H., Hisano, T., Yamazaki, S., Tseng, I.C., 1999. Process behavior of UASB reactor treating a wastewater containing high strength sulfate. Water Res. 33, 3182.

Zhao, Y., Ren, N., Wang, A., 2008. Contributions of fermentative acidogenic bacteria and sulfate-reducing bacteria to lactate degradation and sulfate reduction. Chemosphere 72, 233-242.

Zuhair, S.A., El-Naas, M.H., Hassani, H.A., 2008. Sulfate inhibition effect on sulfate reducing bacteria. J. Biochem. Technol. 1, 39-44. 